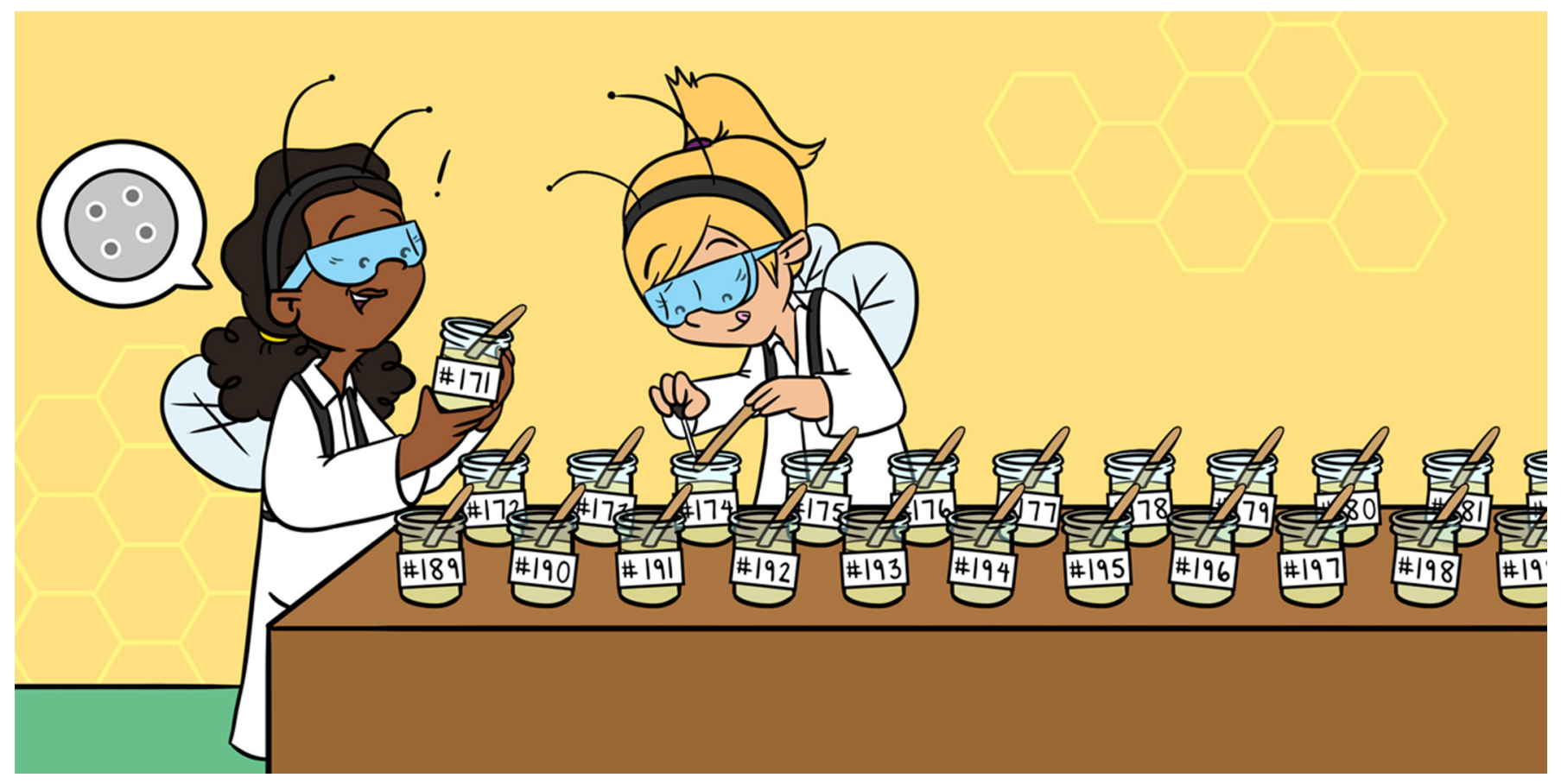

\title{
CAN BEES HELP US FIND NEW ANTIBIOTICS?
}

\section{Kirstie A. Goggin * and Les Baillie}

School of Pharmacy and Pharmaceutical Science, Cardiff University, Cardiff, United Kingdom

\section{YOUNG REVIEWERS:}

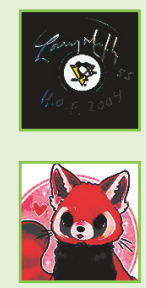

Antibiotics are very important for treating bacterial infections in humans, pets, and livestock. However, improper use of antibiotics has resulted in antibiotic resistance, making it difficult to treat some infections. There is an urgent need to discover new antibiotics, but how do we find them? The answer potentially lies with bees and the honey they produce. Bees who feed on unique plants produce honey with high levels of antibiotic activity, due to the presence of antibacterial compounds in the nectar that the bees collect to make honey. In addition to nectar, the bees also collect pollen, which contains a sample of each visited plant's unique DNA. By studying this DNA, we have identified plants that are sources of the antibacterial compounds found in honey. We are now working to develop new antibiotics from this honey, and we have installed beehives on university buildings to create our own super honey. 
Figure 1

A petri dish

covered with bacteria, showing zones with no bacterial growth around discs that contain antibiotics. This looks much like the sight Professor Alexander Fleming would have seen when mould grew on his petri dishes and prevented his bacteria from growing!

\section{ANTIBIOTICS}

Medicines containing antibacterial compounds, which are used to treat infections.

\section{BACTERIA}

Single-celled organisms that are found in every habitat on earth.

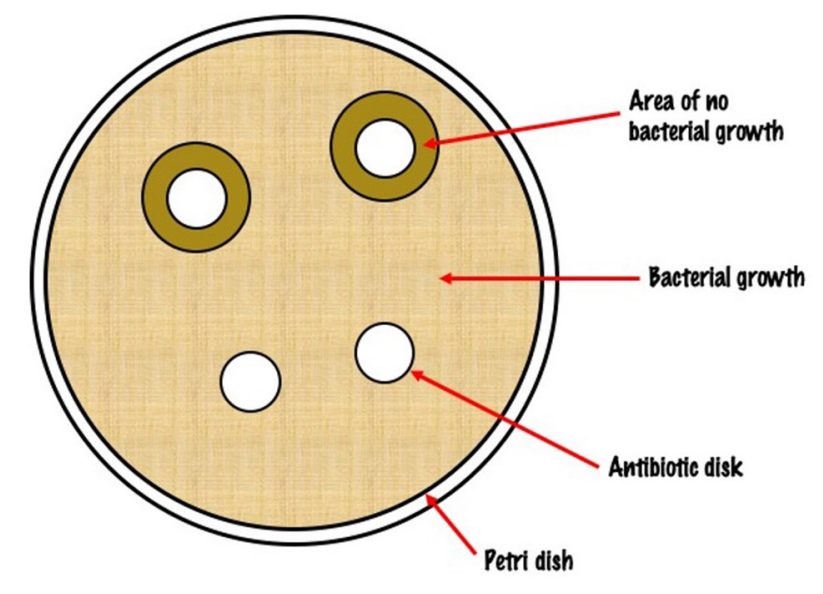

Figure 1

\section{WHAT ARE ANTIBIOTICS AND WHY ARE THEY IMPORTANT?}

Antibiotics are medicines used to treat infections caused by bacteria. Bacteria are tiny organisms that cannot be seen with the naked eye. They consist of a cell wall that surrounds the genetic material and the other components that make up the bacterium. There are $\sim 30,000$ different species of bacteria and they come in all shapes and sizes. Unlike humans and mammals, bacteria reproduce by division, meaning one cell becomes two, two cells become four, and so on. Some bacteria are good for humans and we actually need them to survive, for example, the ones in our digestive tracts, which help us to digest food. However, some bacteria are bad for us and can make us sick.

Antibiotics are compounds that kill bacteria by stopping them from carrying out the activities they need to survive. Some antibiotics work by damaging the cell wall, which stops bacteria from reproducing by division. Others block the production of proteins that the bacteria need to live. In nature, antibiotics are produced by bacteria and fungi to kill their competitors, freeing up more space for them to thrive. Humans have adapted this approach to kill bacteria that are harmful to us!

The most famous antibiotic, penicillin, was discovered by Professor Alexander Fleming in 1928, by accident [1]. He returned from holiday and started sorting through his petri dishes containing colonies of Staphylococcus, which are bacteria that cause boils, sore throats, and abscesses. He noticed that, on one dish, there was an area of mould growing and the zone around the mould had no bacteria, as if the mould had released something that stopped the bacteria from growing (Figure 1). This led to the discovery of penicillin, the first antibiotic. Before antibiotics were discovered, three in 10 deaths were caused by bacterial infections, but thanks to antibiotics, previously deadly infections are now curable! 
ANTIBIOTIC

RESISTANT

\section{BACTERIA}

Bacteria that can survive in the presence of antibiotics.
ANTIMICROBIAL COMPOUNDS

Compounds which can be used to kill bacteria and be harnessed for antibiotics.

\section{WHY DO WE NEED NEW ANTIBIOTICS?}

Bacteria have been around for over 3 billion years and they are one of the most successful life forms on the planet. Given the right conditions, a bacterium like Escherichia coli can divide every 20 min, meaning that in just $7 \mathrm{~h}$, one bacterium can generate over 2 million offspring. Bacteria owe their success to their ability to adapt to changes in their environments much faster than humans can. It was hoped that the widescale use of antibiotics to treat human bacterial infections would reduce the disease-causing potential of these organisms. Unfortunately, as they have always done, bacteria simply adapted to the use of antibiotics and developed mechanisms to avoid their harmful effects - they become antibiotic resistant bacteria.

While there are over 100 different antibiotics, only 10 are routinely used by doctors. Bacteria differ in their sensitivity to various antibiotics, so it is important that doctors prescribe the most effective drug. If the wrong antibiotic is used, not only will the patient fail to get better, but the bacterium might develop antibiotic resistance. Similarly, if an incorrect dose is used or if the prescription is not finished as instructed, antibiotic resistance can also arise. Many people ask their doctors for antibiotics when they have a cough or cold, but their symptoms are often caused by a viral infection, not a bacterial one. Antibiotics do not work against viruses, so it is very important to listen to the doctor and only take antibiotics when we actually need them.

In addition to treating human infections, antibiotics are frequently used by the farming industry to protect farm animals from infections. It is cheaper and less time consuming for farmers to give all of their animals antibiotics, whether they actually have an infection or not. This is a leading cause of antibiotic resistance and it has been banned by the European Union. However, it is still common practice in many parts of the world [2].

As antibiotic resistance increases, the risk increases that antibiotics prescribed by doctors will be unable to cure human illnesses. As a consequence, common, low-risk infections could become life threatening. The UK government commissioned a report predicting that, by 2050, 92 million deaths will occur globally, and 10 million of these will be due to antibiotic resistance [3]. Therefore, we urgently need to find new antibiotics to treat bacterial infections and ensure that people remain healthy.

\section{HOW CAN BEES HELP US FIND NEW ANTIBIOTICS?}

The healing properties of honey have been celebrated for millennia, with the earliest depictions of bees dating back to 4,000 to 5,000 B.C. In addition to containing substances that act like antibiotics, called antimicrobial compounds, honey has also been shown to contain 
Figure 2

We tested our antibacterial super honeys using an experiment called an agar well diffusion assay. Samples of a sugar control (containing no antibacterial substances), Manuka honey, and our honey (Tywyn raw) were added to petri dishes covered in bacteria. After $12 \mathrm{~h}$, we examined the dishes to see whether the control or the honeys prevented the growth of bacteria. For both types of honey, we saw a clear area, called a zone of inhibition, around the spots where the honey was added. These clear zones indicate that the honeys prevented the growth of bacteria.

\section{THERAPEUTIC}

Relating to the healing of disease.

\section{NECTAR}

A sweet liquid in flowers that entices bees towards them.

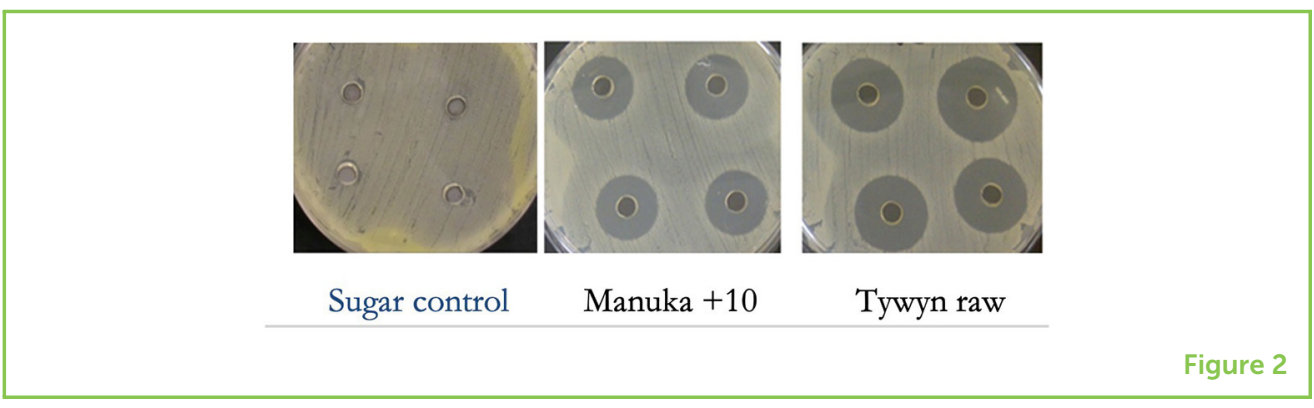

other substances that stimulate the immune system, reduce blood pressure, and otherwise protect cells from damage. Honey and natural products are beneficial for individuals with bacterial infections, and they also help healthy people to remain healthy. Honey has a long history of therapeutic use, particularly when applied to the skin to treat wounds, burns, and skin conditions such as rosacea and cold sores. Medical-grade honey currently used to treat wounds kills infecting bacteria and promotes wound healing by reducing inflammation and pain.

Bees make honey by visiting flowers, where they collect a sugary juice from the blossoms, called nectar, by sucking it out with their tongues. The bees then store nectar in their honey stomachs, which are different from their food stomachs. Once their honey stomachs are full, they fly back to the hive and pass the nectar to other worker bees to chew on. As it is passed from bee to bee, the nectar is gradually turned into honey. The bees store honey in honeycomb cells. At first it is a bit wet, so they fan it with their wings to dry it out and make it stickier. Making honey is no easy task. One bee would have to fly about 90,000 miles to make $500 \mathrm{~g}$ of honey, equal to only about half a bag of sugar. Ninety thousand miles is the same as flying around the world three times! In one collection trip alone, a bee must visit between 50 and 100 flowers.

The antibiotic activity of honey is partly due to the presence of plant-derived antibiotics in the nectar of the plants on which the bees feed. Not all plants contain antibiotic compounds, so samples of honey can differ markedly depending on the plants the bees have visited. For example, Manuka honey is famed for its antibacterial activity, due to the presence of an antibiotic called methylglyoxal in the nectar of the Manuka tree.

\section{IDENTIFYING OUR OWN SUPER HONEY}

To identify our own antibacterial super honey, and the plants responsible, we screened over 200 honey samples donated by beekeepers from across Wales. Our hypothesis was that, by identifying the honey with the highest antibacterial activity, we could then backtrack to identify the plants responsible. Each honey 
Figure 3

Pollen grains extracted from one of the antibacterial honey samples, viewed under an electron microscope. Pollen grains from different types of plants have unique shapes and structures so, using this technique, we could identify which plants our bees visited.

\section{POLLEN}

A fine, powdery substance that plants produce to make seeds.

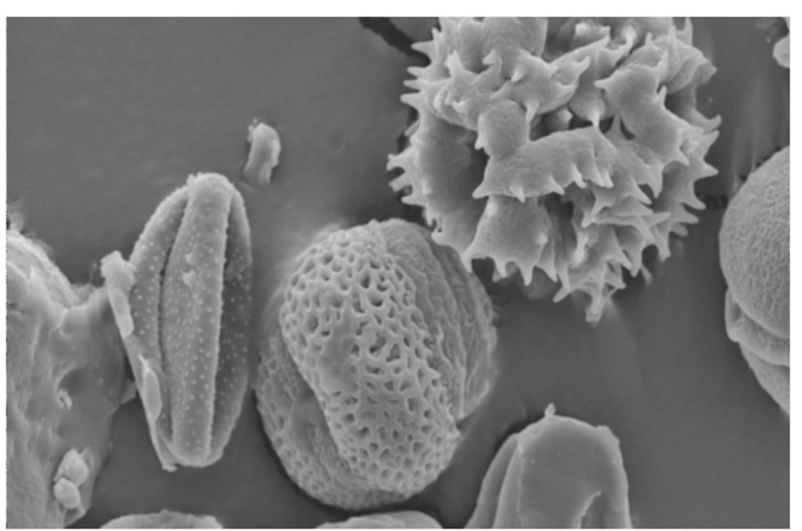

Figure 3

sample was tested in the laboratory for its ability to inhibit the growth of antibiotic-resistant bacteria called methicillin-resistant Staphylococcus aureus (MRSA), which are often found in hospitals. Using this approach, we identified a honey sample from North Wales with similar levels of antibiotic activity as Manaka honey (Figure 2) [4]. The antimicrobial compounds in this honey also had activity against Escherichia coli and Pseudomonas aeruginosa bacteria.

The next step was to identify the plants that were the original source of these antimicrobial compounds. Plants produce nectar to attract bees and to spread their DNA in the form of pollen. As they are feeding on plants, pollen sticks to the bees and is carried to the next plant. This transfer of DNA is known as pollination and it plays a key role in plant reproduction. Fortunately, some of this pollen becomes trapped in the honey, and we were able to identify the plants visited by our bees as they made our super honey, using two laboratory techniques.

First, we used an extremely powerful microscope called an electron microscope to examine the pollen grains from our honey. Under such high magnification, it is easy to see the characteristics of the pollen grains, which gives us clues as to which plants they came from Figure 3. We also removed the DNA from the pollen and analysed it to determine its sequence [5]. The DNA sequences obtained from the pollen could then be compared to the known DNA sequences of many local plants. When the sequences matched, this told which plants were the sources of the pollen in our honey.

\section{THE FUTURE: MAKING NEW DRUGS AND SUPER HONEY!}

As more and more types of bacteria develop resistance to existing antibiotics, it is increasingly important to find new antibiotics to protect humans and animals against dangerous bacterial infections. Work with bees indicates that they may be able to help us! Thanks to the honey 
1 You can find out more about the project on Twitter: apharmabees, Instagram: https://www instagram.com/ pharmabees/ or our website: https://www cardiff.ac.uk/ pharmabees

that bees produce, we have used the pollen found in it, to identify a range of plants that contain naturally high levels of antimicrobial compounds, which could be used to make new antibiotics.

We are currently working to identify the individual compounds from each plant that are responsible for the antibacterial activity we saw in our honey. Once these compounds are identified, it may be possible to develop them into new antibiotics to treat antibiotic-resistant bacteria! To help us with our work, we have installed beehives on Cardiff University buildings and are growing the antibacterial plants on the university campus to provide food for pollinators and to create our own super honey ${ }^{1}$ !

\section{ORIGINAL SOURCE ARTICLE}

Hawkins, J., de Vere, N., Griffith, A., Ford, C. R., Allainguillaume, J., Hegarty, M. J., et al. 2015. Using DNA metabarcoding to identify the floral composition of honey: a new tool for investigating honey bee foraging preferences. PLOS ONE 10:e0134735. doi: 10.1371/journal.p one.0134735

\section{REFERENCES}

1. Tan, S. Y., and Tatsumura, Y. 2015. Alexander Fleming (1881-1955): discoverer of penicillin. Singapore Med. J. 56:366-7. doi: 10.11622/smedj.2015105

2. Guglielmi, G. 2017. Are antibiotics turning livestock into superbug factories. Science. doi: 10.1126/science.aaq0783

3. Public Health England. 2015. Health Matters: Antimicrobial Resistance.

4. Hawkins, J. 2015. Investigating Antibacterial Plant-Derived Compounds From Natural Honey. Cardiff University.

5. Hawkins, J., De Vere, N., Griffith, A., Ford, C. R., Allainguillaume, J., Hegarty, M. J., et al. 2015. Using DNA metabarcoding to identify the floral composition of honey: a new tool for investigating honey bee foraging preferences. PLOS ONE 10:e0134735.doi: 10.1371/journal.pone.0134735

SUBMITTED: 29 September 2020; ACCEPTED: 22 June 2021;

PUBLISHED ONLINE: 13 July 2021.

EDITED BY: Kunkai Su, Zhejiang University, China

CITATION: Goggin KA and Baillie L (2021) Can Bees Help us Find New Antibiotics? Front. Young Minds 9:611604. doi: 10.3389/frym.2021.611604

CONFLICT OF INTEREST: The authors declare that the research was conducted in the absence of any commercial or financial relationships that could be construed as a potential conflict of interest. 

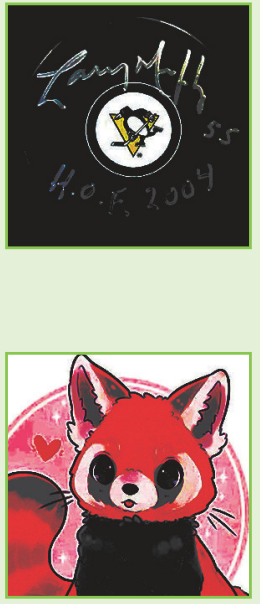

COPYRIGHT () 2021 Goggin and Baillie. This is an open-access article distributed under the terms of the Creative Commons Attribution License (CC BY). The use, distribution or reproduction in other forums is permitted, provided the original author(s) and the copyright owner(s) are credited and that the original publication in this journal is cited, in accordance with accepted academic practice. No use, distribution or reproduction is permitted which does not comply with these terms.

\section{YOUNG REVIEWERS}

\section{BENJAMIN, AGE: 14}

When I was introduced into this world, I first lived in an apartment with my dad and mom. Life was great, I had no responsibilities to take care of. Three years later, my sister joined us. After 5 years, I left that apartment to live in a house. This was also when I was introduced to hockey. When I started my middle school, we moved into a giant house, after that our life has been going smoothly.

\section{BREANNA, AGE: 11}

Hello! I am a fifth grader! I am very funny when I am with friends but shy around strangers. I have six friends. I like watching movies, and I read books when I am bored. I like drawing and I love watching on my phone. I have a brother and a helpful mom and dad. My house has a surrounding of many trees and beautiful birds. My favorite foods are ice-cream, banana bread, and pasta. I like being myself!

\section{AUTHORS}
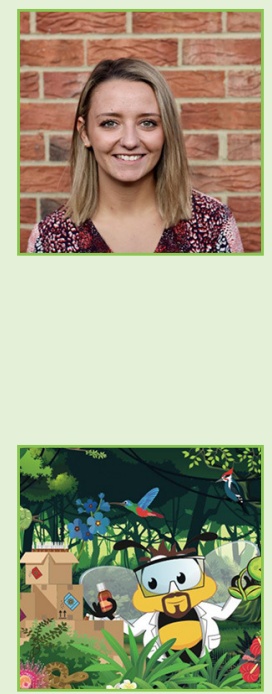

\section{KIRSTIE A. GOGGIN}

I am a post-doctoral research associate, researching antimicrobial compounds in green tea. I am developing a blend of tea that will be optimised to have beneficial levels of certain anti-inflammatory and antimicrobial compounds and will hopefully be used to treat urinary tract infections. I have an undergraduate degree in international wildlife biology and am interested in working with nature to tackle challenges such as antimicrobial resistance and sustainable food production. *kirstieamtlprojects.com

\section{LES BAILLIE}

I am a professor of microbiology and I lead a group attempting to identify new antibiotics in natural products such as honey and tea. Prior to joining Cardiff University, I worked for the U.S. Navy and the U.K. Ministry of Defence, countering the threat of bacterial pathogens. I currently lead the Cardiff University's award-winning Pharmabees Project, which attempts to educate the public about the importance of pollinators and biodiversity. 